\title{
Juvenile weakfish Cynoscion regalis distribution in relation to diel-cycling dissolved oxygen in an estuarine tributary
}

\author{
Robin M. Tyler ${ }^{1, *}$, Timothy E. Targett ${ }^{2}$ \\ ${ }^{1}$ Environmental Laboratory Section, Division of Water Resources, Delaware Department of Natural Resources and \\ Environmental Control, 89 Kings Highway, Dover, Delaware 19901, USA \\ ${ }^{2}$ College of Marine and Earth Studies, University of Delaware, Lewes, Delaware 19958, USA
}

\begin{abstract}
Shallow estuarine waters that serve as nurseries for fishes along the Atlantic and Gulf coasts of the USA can undergo wide diel dissolved oxygen (DO) fluctuations $\left(<2\right.$ to $\left.\sim 20 \mathrm{mg} \mathrm{O} \mathrm{O}_{2} \mathrm{l}^{-1}\right)$ during summer. In this study, the distribution of juvenile weakfish Cynoscion regalis was investigated in relation to diel-cycling DO during summer 2001 in a mesohaline tributary of Indian River Bay, Delaware, USA. Weakfish were collected at 3 sites (upper, middle, and lower) along the $\sim 5 \mathrm{~km}$ length of Pepper Creek on $15 \mathrm{~d}$ using an otter trawl. Near-bottom DO was monitored continuously over the summer, every $15 \mathrm{~min}$, using multi-parameter sondes. Peak abundance of weakfish coincided with the greatest frequency, intensity, and spatial extent of severe diel-cycling hypoxia events $\left(<2 \mathrm{mg} \mathrm{\textrm {O } _ { 2 }}\right.$ $\left.\mathrm{l}^{-1}\right)$. Severe hypoxia first occurred in early June in the upper creek and recurred there almost daily for periods of 1 to $4 \mathrm{~h}$ until early September. Whenever bottom DO was $>2.0 \mathrm{mg} \mathrm{O}_{2} \mathrm{l}^{-1}$, weakfish were more abundant at the upper site than at the middle and lower sites, which also experienced severe hypoxia but at much lower frequency. However, under all environmental conditions they were absent from the upper site whenever bottom DO was $<2 \mathrm{mg} \mathrm{O}_{2} \mathrm{l}^{-1}$, and returned within $2 \mathrm{~h}$ of DO exceeding $2 \mathrm{mg} \mathrm{O}_{2} \mathrm{l}^{-1}$. Daily up- and down-creek movement occurred over a distance of $\sim 1 \mathrm{~km}$. These findings indicate an avoidance threshold of $\sim 2.0 \mathrm{mg} \mathrm{O}_{2} \mathrm{l}^{-1}$ for juvenile weakfish and demonstrate very temporally dynamic DO-related movement. Their rapid return to these areas as DO conditions improve, and relatively high density in tidal tributary headwaters, suggests that these relatively small areas provide important habitat for fishes.
\end{abstract}

KEY WORDS: Hypoxia · Estuary $\cdot$ Coastal waters

\section{INTRODUCTION}

Worldwide, estuarine habitats utilized by the juveniles of many marine fishes are increasingly impacted by summer hypoxia events resulting from elevated eutrophication rates (Diaz \& Rosenberg 1995, Diaz et al. 2004). These hypoxia events range in intensity from moderate $\left(2\right.$ to $\left.5 \mathrm{mg} \mathrm{O}_{2} \mathrm{l}^{-1}\right)$ to severe $\left(<2 \mathrm{mg} \mathrm{O}_{2} \mathrm{l}^{-1}\right)$ and persist for durations that range from hours (Breitburg 1992, D'Avanzo \& Kremer 1994, Tyler 2004) to days (Stanley \& Nixon 1992, Eby \& Crowder 2002) and from weeks to months (Officer et al. 1984, Price et al. 1985).
Conclusions regarding fish responses to hypoxia in the field (i.e. avoidance and mortality) have generally been based on the presence/absence and relative abundance of fishes (Garlo et al. 1979, Howell \& Simpson 1994, Maes et al. 1998, Eby \& Crowder 2002). These studies have suggested that the primary cause of observed reductions in fish abundance in areas with severe hypoxia, compared to higher abundances in adjacent areas with higher DO, is avoidance rather than mortality.

Several field studies in US coastal waters have reported sharp reductions in the abundance of most fishes at DO (dissolved oxygen) concentrations $<2 \mathrm{mg}$ 
$\mathrm{O}_{2} \mathrm{l}^{-1}$ (Garlo et al. 1979, Pihl et al. 1991, Lenihan et al. 2001, Eby \& Crowder 2002, Bell \& Eggleston 2005), while Howell \& Simpson (1994) observed reductions in species richness when DO declined below $3 \mathrm{mg} \mathrm{O}_{2} \mathrm{l}^{-1}$. These concentrations are not much above the lethal DO concentrations ( $\mathrm{LC}_{50}$ values) determined for the juvenile stage of some estuary-dependent fishes (Burton et al. 1980, USEPA 2000, Miller et al. 2002) and they overlap concentrations shown to be detrimental for growth (Bejda et al. 1992, USEPA 2000, Stierhoff et al. 2006). For example, juvenile summer flounder Paralichthys dentatus have a $24 \mathrm{~h} \mathrm{LC}_{50}$ of $1.59 \mathrm{mg} \mathrm{O}_{2} \mathrm{l}^{-1}$ at 24 to $25^{\circ} \mathrm{C}$ (USEPA 2000), and their growth rate is reduced by $\sim 25 \%$ at $3.5 \mathrm{mg} \mathrm{O}_{2} \mathrm{l}^{-1}$ (compared to normoxia, i.e. $7 \mathrm{mg} \mathrm{O}_{2} \mathrm{l}^{-1}$ ) and by 50 to $60 \%$ at $2 \mathrm{mg} \mathrm{O}_{2} \mathrm{l}^{-1}$ and 20 to $25^{\circ} \mathrm{C}$ (Stierhoff et al. 2006). For juveniles of other fish species and functional groups common in estuarine nursery areas, the USEPA (2000) reported $24 \mathrm{~h} \mathrm{LC}_{50}$ values of 0.7 and $1.4 \mathrm{mg} \mathrm{O}_{2} \mathrm{l}^{-1}$ for spot Leiostomus xanthurus and winter flounder Pseudopleuronectes americanus, respectively, and a $96 \mathrm{~h} \mathrm{LC_{50 }}$ of $1.04 \mathrm{mg} \mathrm{O}_{2} \mathrm{l}^{-1}$ for Atlantic menhaden Brevoortia tyrannus. Spot and Atlantic menhaden exposed to $1.2 \mathrm{mg} \mathrm{O}_{2}$ $\mathrm{l}^{-1}$ for $24 \mathrm{~h}$ experience no mortality at $25^{\circ} \mathrm{C}$, and 30 to $40 \%$ mortality at $30^{\circ} \mathrm{C}$, but both species exhibited $100 \%$ mortality within 2 to $6 \mathrm{~h}$ at $0.6 \mathrm{mg} \mathrm{O}_{2} \mathrm{l}^{-1}$ (Shimps et al. 2005).

Miller et al. (1985) reported that juvenile fishes are more tolerant than adults of the relatively wide ranges in environmental variables such as DO, temperature, salinity, and turbidity that occur in estuarine nursery areas. It follows that juvenile fishes may be expected to penetrate farther than older conspecifics into the shallow, highly productive upper segments of estuaries, where temperature, feeding conditions, and risk of predation may be more favorable for growth and survival. Several studies have, in fact, reported increased numbers of transient juvenile fishes with distance into estuaries (Gunter 1957, Massman 1971, Paterson \& Whitfield 2000, Meng et al. 2002, Kirby-Smith et al. 2003).

It is notable that many fishes common as juveniles during summer in tributaries of US mid-Atlantic estuaries (e.g. weakfish, summer flounder, spot, and menhaden) spend their larval and post-larval periods in the coastal ocean during winter and spring, when hypoxia is not a factor. Despite the relative tolerance of juvenile fishes to low DO conditions that can develop in portions of estuarine nursery areas, they must move or die when hypoxia becomes too severe. It has been considered elsewhere that fishes which move in response to hypoxia and are then squeezed into a compressed habitat where [DO] is higher may experience increased predation rates and lower growth rates due to complications such as energetic costs of avoiding predators, increased competition for food, and/or exposure to less favorable abiotic conditions (Miller et al. 1985, Eby \& Crowder 2002, Eby et al. 2005). Conversely, it has been shown that severe hypoxia forces sessile infauna to reposition close to, or onto, the sediment surface where they become easy prey for motile animals that return to the area when DO reaches an adequate level, but before the sessile benthic organisms are able to reburrow (Pihl et al. 1991, 1992, Nestlerode \& Diaz 1998).

Most studies that address coastal hypoxia (Officer et al. 1984, Price et al. 1985, Stanley \& Nixon 1992, Eby \& Crowder 2002) and related effects on fishes (Garlo et al. 1979, Pihl et al. 1991, Lenihan et al. 2001, Eby \& Crowder 2002) have been conducted in stratified waters where severe hypoxia develops beneath the pycnocline and events range in duration from days to months. Our study was conducted in a system where DO fluctuates over the diel cycle (24 h) as a function of biological activity (photosynthesis and respiration), with the lowest and highest concentrations typically occurring in the early morning and late afternoon, respectively (D'Avanzo \& Kremer 1994, Beck \& Bruland 2000, Tyler 2004). Waters in which diel-cyclic DO fluctuation predominates can include the upper few meters above the pycnocline in deeper systems (Kemp $\&$ Boynton 1980) or the entire water column in very shallow waters that do not have a pycnocline (Tyler 2004).

In the present study, we examined spatial and temporal dynamics in distribution and abundance of juvenile weakfish Cynoscion regalis relative to diel-cycling DO conditions along the longitudinal axis of Pepper Creek, an estuarine tributary on the US mid-Atlantic coast. Pepper Creek is typical of small estuarine tributaries that occur along the landward edges of midAtlantic coastal lagoons with respect to temporal and spatial variability in DO conditions that may influence avoidance behavior and, therefore, distribution of fishes. The weakfish is of high economic importance, is representative of demersal estuary-dependent fishes, and is consistently one of the most abundant species in the study area (Michels 1986-2005, Tyler 2004). In the year the present study was conducted (2001), it was the only species that occurred in sufficient abundance at the right time of the season to address the research goals. The goals were to: (1) determine the threshold for hypoxia-induced avoidance behavior by juvenile fish (weakfish) by establishing the [DO] at which they no longer occurred at selected sampling areas and (2) determine the temporal and spatial scales of dynamics in distribution and abundance relative to diel-cycling DO conditions.

It is important to better understand the dynamics of fish distribution relative to short-term (diel) changes in DO. Information on relationships between specific DO 
conditions that initiate fish movement and the rapidity with which fish repopulate areas that are intermittently uninhabitable due to severe hypoxia will help elucidate the ecological impacts of short-term (dielcycling) hypoxia dynamics on fishes in shallow estuarine habitats.

\section{MATERIALS AND METHODS}

To conduct this study it was necessary to locate a sampling area where (1) the depth was sufficient to trawl at all tide stages, (2) the [DO] fell low enough to potentially cause avoidance behavior in fishes and did so frequently enough to allow numerous hypoxia events to be sampled, and (3) juvenile fish abundance was sufficiently high to ensure sample sizes large enough to define relationships between DO conditions and fish distribution.

Study area. Pepper Creek, a mesohaline tributary of Indian River Bay, Delaware, USA (Fig. 1), met the design requirements. The average mean low water

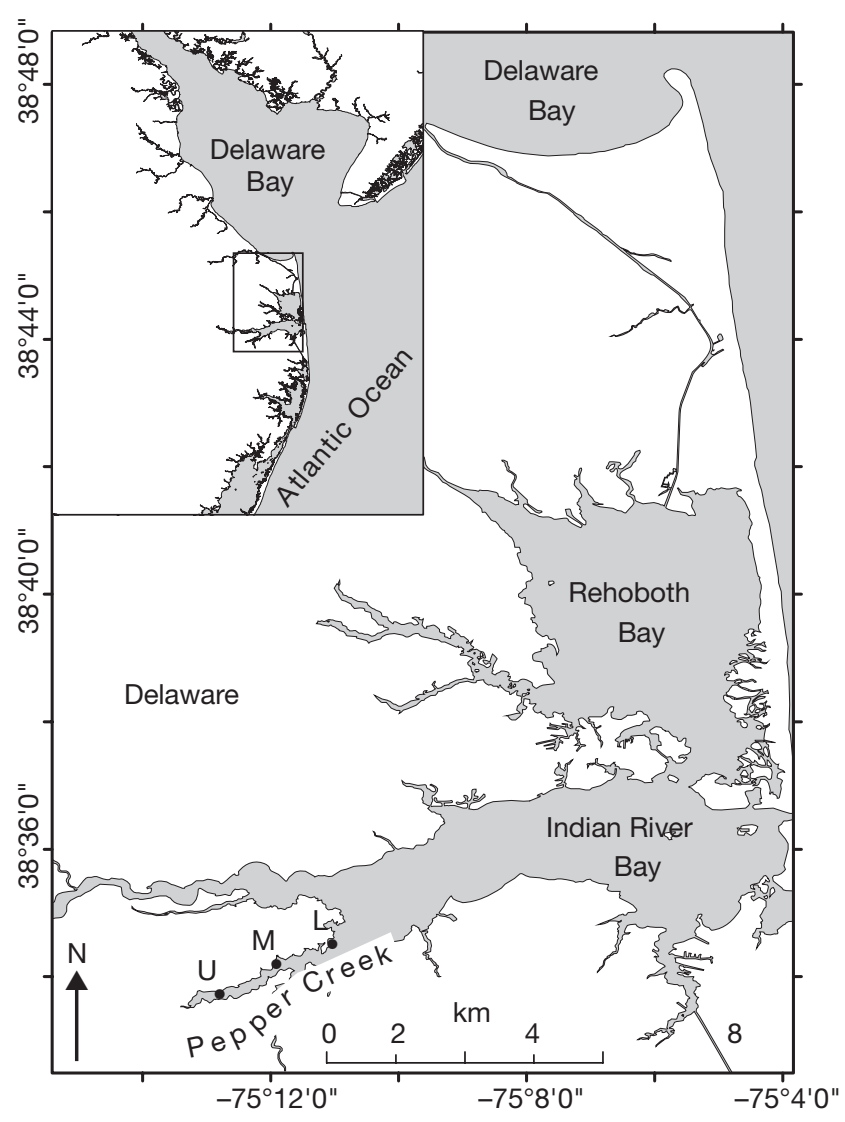

Fig. 1. Pepper Creek, a tributary of Indian River Bay in the Delaware coastal bays. Juvenile fishes were sampled in conjunction with dissolved oxygen monitoring at 3 sites (U: upper; M: middle; L: lower) from 18 May to 20 September 2001
(MLW) depth is $\sim 0.5 \mathrm{~m}$, with a narrow navigation channel of $\sim 1.5 \mathrm{~m} \mathrm{MLW}$ and a tidal differential of $\sim 0.75 \mathrm{~m}$. Creek width ranges from $\sim 0.75$ to $\sim 0.15 \mathrm{~km}$ at the lower and upper ends of the sampling area, respectively. Sediments are primarily soft mud, devoid of vegetation, except for low-density patches of macroalgae (predominantly Ulva, Gracilaria, and Aghardiella).

During summer, turbidity is high due to heavy phytoplankton density that increases with distance up the tributary (Tyler 2004). Dissolved oxygen fluctuation is diel-cyclic and, during summer, the $24 \mathrm{~h}$ range can be extreme (0 to $>300 \%$ saturation) (Tyler 2004). The extent of the diel DO range is largely driven by the photosynthesis and respiration cycles of phytoplankton (chlorophyll a concentrations are typically $<40 \mu \mathrm{g}^{-1}$ in the lower creek and are frequently $>200 \mu \mathrm{g} \mathrm{l}^{-1}$ in the upper creek) (Tyler 2004). Salinity (15 to $25 \mathrm{ppt}$ ) typically ranges from $\sim 3$ to 5 ppt over the tide cycle, and heavy rain events can cause further reduction in the upper creek to $<10$ ppt for durations of hours to a few days (Tyler 2004). Temperature fluctuation is also dielcyclic and varies during summer by $\sim 5^{\circ} \mathrm{C}$, with the lowest levels occurring around dawn (mid-20s ${ }^{\circ} \mathrm{C}$ ) and the highest in the late afternoon (low 30s ${ }^{\circ} \mathrm{C}$ ) (Tyler 2004).

Dissolved oxygen monitoring and fish sampling. Dissolved oxygen monitoring proceeded continuously from 18 May to 20 September, 2001 at 3 sites in Pepper Creek (Fig. 1), and within this period sampling of juvenile fishes was conducted on 20 interspersed dates (weakfish Cynoscion regalis were present on the last 15 dates). Near-bottom ( $15 \mathrm{~cm}$ above sediment-water interface) DO, temperature, and salinity were measured at 15 min intervals using Yellow Springs Instruments (YSI) multi-parameter sondes (Model 6920 and $600)$. Sondes were suspended from portable stanchions (see Tyler 2004).

Vertical variability in DO, temperature, and salinity was determined by taking measurements from surface-to-bottom at $0.3 \mathrm{~m}$ depth increments (profiling) using a YSI Model 85 meter. All vertical measurements were taken while at anchor in the channel. Profiling occurred on 9 dates between mid-July and earlySeptember and was focused at the upper creek site where the frequency and intensity of severe hypoxia events were greatest. To determine how water column [DO] changed over the course of the day, at least 3 profiles were conducted on each of the 9 dates, with the first profile occurring near sunrise and the last in the early afternoon. On 4 dates, when the first profile at the upper creek site revealed severely hypoxic conditions and fish were absent, a profile was immediately done at the middle creek site to determine DO conditions there, followed by trawling to determine fish abundance. 
Juvenile fishes were sampled near each sonde using a $3 \mathrm{~m}$ otter trawl with net and cod-end mesh sizes of 15 and $5 \mathrm{~mm}$, respectively. A $3 \mathrm{~m}$ segment of $6.4 \mathrm{~mm}$ diameter chain was added to the ground rope to enhance bottom contact. At each site, 4 trawl tows of $100 \mathrm{~m}$ each (referred to as a trawling event) were conducted against the tide, while maintaining a constant boat speed of $\sim 3.2$ to $4.0 \mathrm{~km} \mathrm{~h}^{-1}$. Due to the fixed locations of the sondes and the small size of the creek, the trawling locations were also relatively fixed ( \pm ca. $50 \mathrm{~m}$ between sampling days and events).

Fish were counted and measured in the field to the nearest millimeter (total length, TL). During some trawling events several hundred juvenile weakfish were caught. On these occasions a representative subsample ( 75) was measured.

Three fish sampling approaches were employed. The first approach determined spatial and temporal distribution and abundance of weakfish among and within sites by trawling on all 20 sampling days during mid-day (between 10:00 and 15:00 h), when DO was seldom $<2 \mathrm{mg} \mathrm{O}_{2} \mathrm{l}^{-1}$. The second approach determined the minimum DO at which weakfish occurred in abundance by conducting additional trawling at the upper site (where diel-cycling hypoxia was most severe) on 9 sampling days between 13 July and 6 September. The first trawling event was done near sunrise when DO was typically at its lowest of the diel cycle. The timing of subsequent trawling events at the upper site on these $9 \mathrm{~d}$ (aside from the mid-day event) was based upon multiple factors including presence or absence of fish in the first trawling event, bottom DO in subsequent vertical profiles, and tidal phase and stage. For example, when fish were absent or very scarce near sunrise in the upper creek (which was always the case under severely hypoxic conditions $\left(<2 \mathrm{mg} \mathrm{O}_{2} \mathrm{l}^{-1}\right)$, trawling was not done again until DO reached at least $2 \mathrm{mg} \mathrm{O}_{2} \mathrm{l}^{-1}$. This second trawling event and subsequent events (the last of which was the mid-day event) were done to establish the level of abundance and rapidity with which weakfish repopulated the upper creek. The third approach determined the distance weakfish moved down the creek to avoid severely hypoxic conditions by trawling at the middle site (where bottom DO was usually $\geq 2 \mathrm{mg} \mathrm{O}_{2} \mathrm{l}^{-1}$ ), immediately following 4 of the 9 sunrise trawling events in which fish were absent from the upper site. Collectively, these findings were used to determine the area of the creek that was temporarily vacated by juvenile fishes and to further define the minimum DO at which fish were abundant.

Statistical analyses. The strength of the association between DO concentration at the time of trawling and the number of juvenile weakfish collected was tested using a Kendall rank correlation analysis (Sokal \&
Rohlf 2001). Differences in juvenile weakfish abundance among sites were tested using a 2-way, mixedmodel ANOVA without replication (Sokal \& Rohlf 2001), in which site was a fixed factor and date was a random factor, using SYSTAT 11.

\section{RESULTS}

\section{Dissolved oxygen conditions}

Continuous sonde measurements showed that nearbottom DO followed a diel $(24 \mathrm{~h})$ pattern with minimum DO around sunrise, increasing through daytime and decreasing through nighttime. Fig. 2 is a typical example of this pattern. Severe hypoxia $\left(<2 \mathrm{mg} \mathrm{O}_{2} \mathrm{l}^{-1}\right)$ occurred at a much greater frequency and intensity at the upper creek site than at the middle and lower sites (Fig. 3) and was rare at all sites when nighttime low water temperature was $<25^{\circ} \mathrm{C}$.

Severe hypoxia events occurred at the upper site between 8 June and 11 September. During this period, on all but 2 dates, severe hypoxia occurred for periods of several minutes to $>5 \mathrm{~h}$ and accounted for $19 \%$ of the total time. Over $90 \%$ of these severe hypoxia measurements occurred between midnight and noon, with $72 \%$ occurring between 04:00 and 09:00 h. At the middle and lower sites, DO was $<2 \mathrm{mg} \mathrm{O}_{2} \mathrm{l}^{-1}$ for much less time, accounting for only $2 \%$ of measurements at each site.

Profiling results showed that vertical variation in DO was typically least around sunrise before the onset of algal photosynthesis (Fig. 4, left column of profiles). On sunny days during early daytime, despite the relative shallowness of the channel ( 1.5 m MLW), DO increase at the bottom typically lagged behind that at the sur-

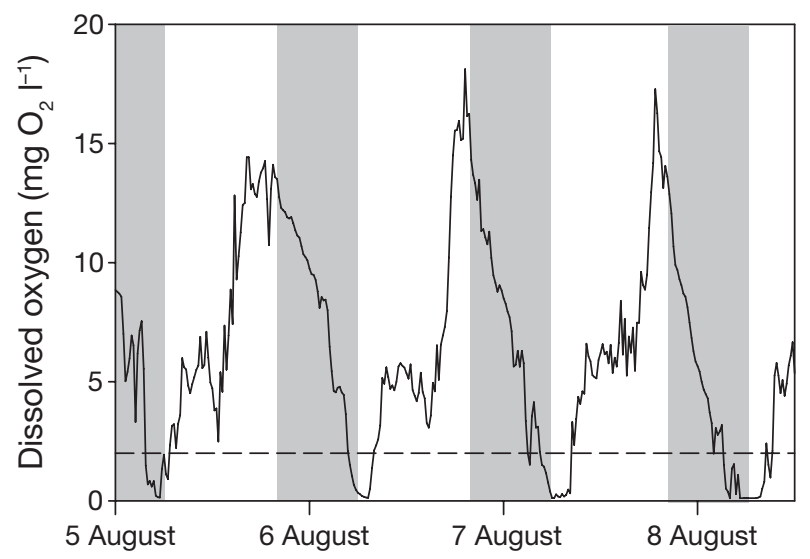

Fig. 2. Diel-cycling dissolved oxygen from 00:00 h on $5 \mathrm{Au}-$ gust to $11: 45$ h on 8 August 2001 at the upper Pepper Creek site. Sunrise to sunset (06:00 to 08:00 h) is unshaded. Hypoxia is considered severe below the horizontal line at $2 \mathrm{mg} \mathrm{O}_{2} \mathrm{l}^{-1}$ 


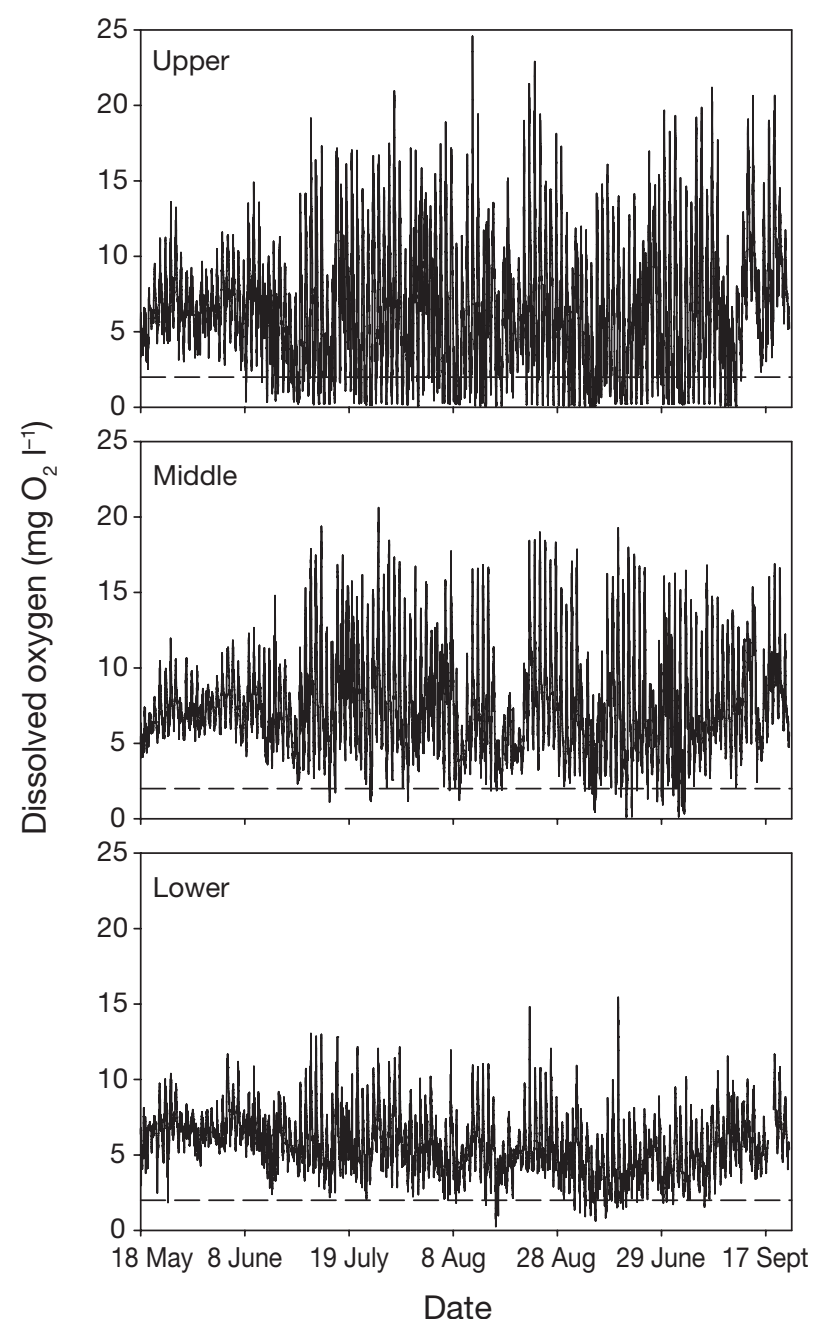

Fig. 3. Dissolved oxygen at the upper, middle, and lower Pepper Creek sites from 18 May to 20 September 2001. The horizontal dashed line indicates severe hypoxia $\left(2 \mathrm{mg} \mathrm{O}_{2} \mathrm{l}^{-1}\right)$

face by 1 to $2 \mathrm{~h}$ (Fig. 4). The difference between surface and bottom [DO] could be large (10 to $15 \mathrm{mg} \mathrm{O}_{2}$ $\mathrm{l}^{-1}$ ) on sunny afternoons when phytoplankton production rates were highest (Fig. 4a,d,e,f,g,i).

A tide effect on DO was evident. When at near sunrise the tide was low or in late ebb the entire water column was often severely hypoxic (Fig. 4c,e,f). In contrast, when at near sunrise the tide was rising or in early ebb, the entire water column was usually moderately hypoxic to normoxic (Fig. 4b,d). A deviation from this contrasting DO pattern is illustrated by Fig. 4g, in which the entire water column was severely hypoxic, or nearly so, at sunrise, even though the tide was in early ebb.

The near-sunrise, high-tide severe hypoxia condition shown in Fig. $4 \mathrm{~g}$ appeared to be weather related. Over the several days and nights prior to this sampling event air temperature was unusually high, and $2 \mathrm{~d}$ prior to sampling a strong thunderstorm occurred that resulted in heavy rainfall followed by relatively high freshwater inflow. These conditions resulted in a combination of very high water temperature and strong vertical salinity stratification (Fig. 5c). By contrast, the moderately hypoxic conditions shown in Fig. 5a and 5b were not associated with combined extremes of water temperature and salinity.

The greater frequency and magnitude of severe hypoxia events at the upper site, large vertical variation in DO over periods of minutes to hours, and the effect of tidal stage on hypoxia severity provided the opportunity to examine fish distribution and abundance in relation to diel-cycling DO fluctuation.

Weakfish Cynoscion regalis distribution and abundance relative to dissolved oxygen. Over the entire study period, the mid-day trawl catches at all 3 Pepper Creek sites collectively included 30 fish species, with juvenile weakfish accounting for $70 \%$ of all fish caught (Tyler 2004). Of the total number of weakfish caught, $52 \%$ was taken at the upper site and $24 \%$ was taken at each of the other 2 sites.

The first appearance of weakfish was at the lower site on 18 June, at which time their average TL was $\sim 25 \mathrm{~mm}$. By 27 June they were distributed throughout the creek, with similar numbers collected at all 3 sites (Fig. 6). Peak abundance occurred from mid-July through mid-August. Beginning on 25 July abundance was significantly higher at the upper site (2-way ANOVA, p < 0.001), where daily catch rates were a factor of 5 to 2 orders of magnitude higher than at the middle and lower sites. After 31 July, they were absent from the lower site and scarce at the middle site (Fig. 6), despite much higher minimum daily DO values (at both sites) and more stable (smaller range) DO conditions (lower site) than those that existed at the upper site (Fig. 3). By 6 September weakfish were absent from the middle site and had become much less abundant at the upper site. By that time their average TL had reached $\sim 140 \mathrm{~mm}$. Sampling ended on 20 September, when only 2 individuals were caught at the upper site. It was concluded that this sharp reduction in abundance was due to seasonal emigration rather than a DO response.

Although the seasonal patterns of juvenile weakfish distribution and abundance did not appear to be DO related, there were striking short-term (hours) dynamics in distribution patterns associated with changes in DO. Overall, the following examples illustrated in Fig. 7 show that, given adequate $\mathrm{DO}$ levels (i.e. $>2 \mathrm{mg} \mathrm{O}_{2}$ $\mathrm{l}^{-1}$ ), juvenile weakfish were present in the upper creek regardless of time of day or tidal stage and that the number of juvenile weakfish collected at any time was significantly correlated with DO (Kendall tau $=0.449$, $\mathrm{p}<0.01)$. 


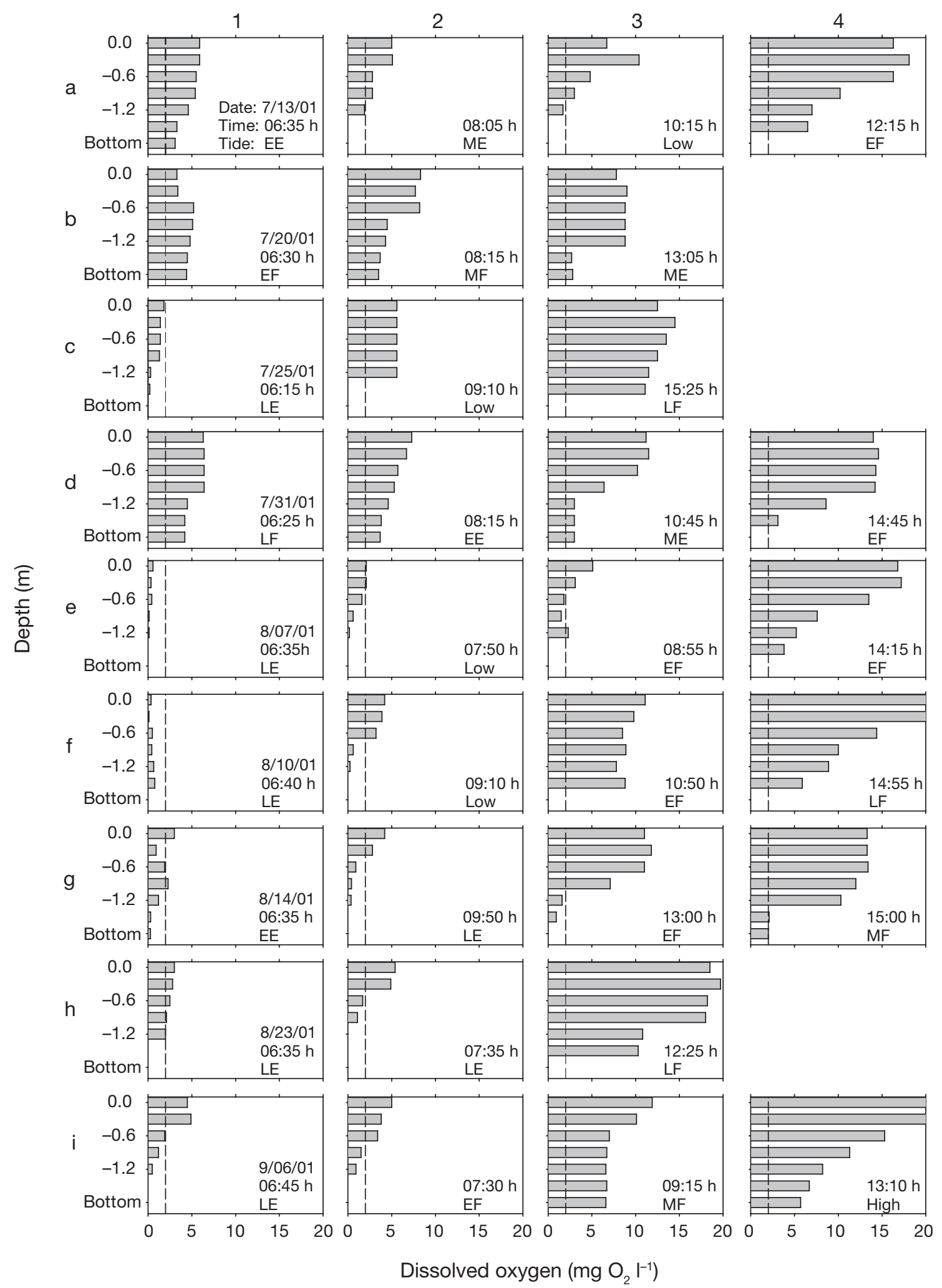

Fig. 4. Vertical profiles of dissolved oxygen (DO) at the upper Pepper Creek site on 9 dates (a-i) in 2001. Profiles in the left column were taken $<45$ min after sunrise. The top bar in each profile is DO at the water surface, each subsequent bar represents a depth interval of $0.3 \mathrm{~m}$, and the bottom bar is DO at the bottom. Tide stage is denoted as early (E), middle (M), or late (L), and tide phase, as ebb $(\mathrm{E})$, flood $(\mathrm{F})$, low, or high. Vertical dashed line indicates severe hypoxia $\left(2 \mathrm{mg} \mathrm{O}_{2} \mathrm{l}^{-1}\right)$. Dates given as mo/d/yr 

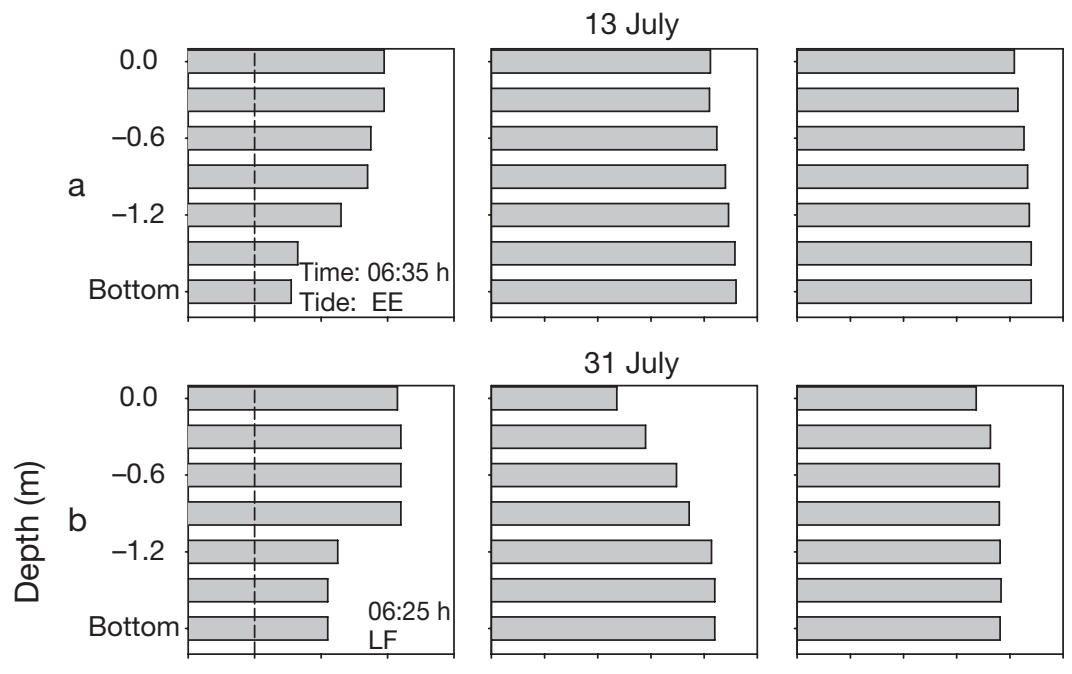

14 August
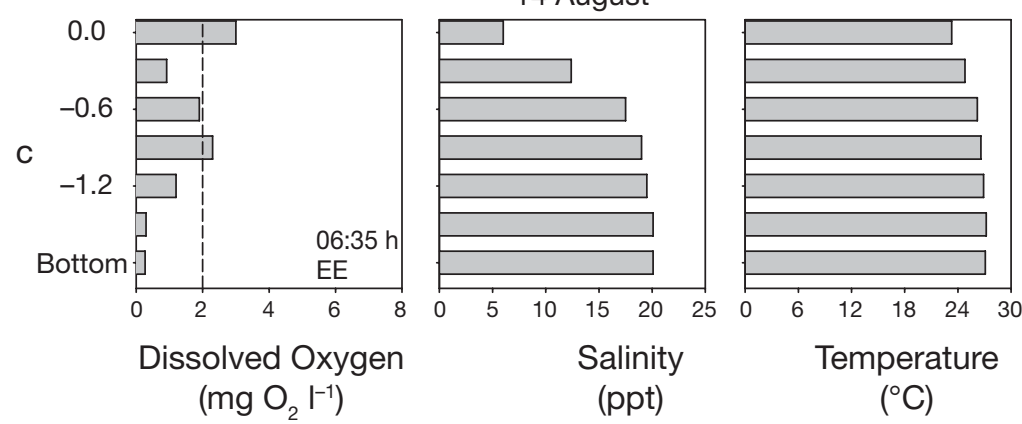

Fig. 5. Vertical profiles of dissolved oxygen, salinity, and temperature $(<45 \mathrm{~min}$ after sunrise, near high tide) at the upper Pepper Creek site on 3 dates (a to c) in 2001. The top bar in each profile is condition at the water surface; each subsequent bar represents a depth interval of $0.3 \mathrm{~m}$, and the bottom bar is condition at the bottom. Tide is denoted as early ebb (EE) or late flood (LF). Vertical dashed line indicates severe hypoxia $\left(2 \mathrm{mg} \mathrm{O}_{2} \mathrm{l}^{-1}\right)$

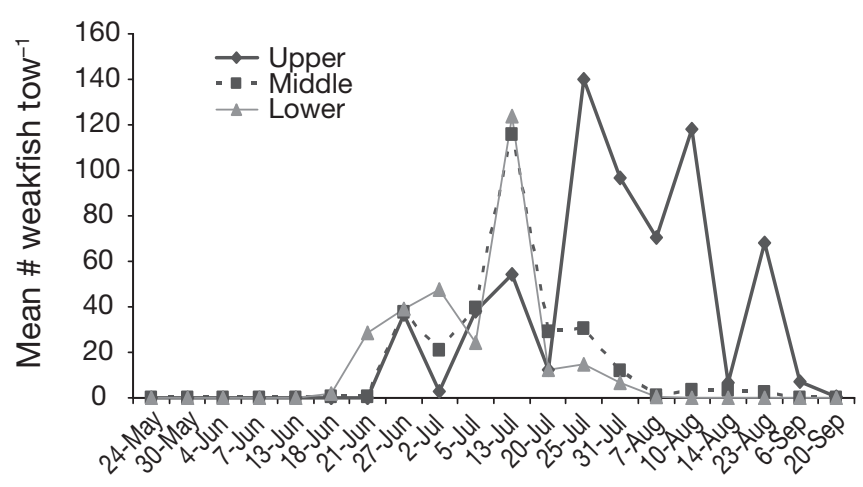

Fig. 6. Comparisons of juvenile weakfish Cynoscion regalis catches (each data point a mean of four $100 \mathrm{~m}$ trawl tows) at upper, middle, and lower Pepper Creek sites during the summer of 2001

For example, on 13 July weakfish were very abundant during the sunrise trawling event (06:45 h) at the upper site, the timing of which coincided with a relatively low bottom DO of $2.1 \mathrm{mg} \mathrm{O}_{2} \mathrm{l}^{-1}$ (Fig. 7a). It is notable that $<1 \mathrm{~h}$ prior to this low measurement the DO was $\sim 4 \mathrm{mg} \mathrm{O} \mathrm{O}^{-1}$ (Fig. 7a). The next trawling event was conducted at 08:45 h, during which DO remained close to $2 \mathrm{mg} \mathrm{O} \mathrm{O}_{2} \mathrm{l}^{-1}$, and weakfish abundance was considerably lower. During the $2 \mathrm{~h}$ period preceeding fish had apparently moved down the creek with the ebbing tide to avoid the low DO conditions. By the time of the third trawling event $(12: 30 \mathrm{~h}), \mathrm{DO}$ had increased substantially (although the tide had just begun to rise) and juvenile weakfish were abundant again (Fig. 7a).

This pattern of few or no weakfish present in the upper creek early in the daytime (during the sunrise trawling event), followed by increased numbers associated with increased DO was the common observed pattern (Fig. 7c,e,f, $g, h, i)$. On the 2 sampling days when weakfish were present in the upper creek during the sunrise trawling event, although at different levels of abundance, the DO was $>4 \mathrm{mg} \mathrm{O}_{2} \mathrm{l}^{-1}$ (Fig. 7b,d).

On 5 of the 6 sampling days when no weakfish were caught during the sunrise trawling event, their absence coincided with mid-ebb to low tide stages, as well as severe hypoxia (Fig. 7c,e,f, $\mathrm{h}, \mathrm{i})$. This pattern could be taken to suggest that fish move with the tide and are not in the upper creek during mid-ebb to low tide, even under high DO conditions. This possibility is unlikely, based on results from occasions when DO was $>2 \mathrm{mg} \mathrm{O}_{2} \mathrm{l}^{-1}$ during mid-ebb to low tide. On 25 July weakfish were absent during the last of the ebb tide under severely hypoxic conditions, yet during slack low water, when the DO was $>5 \mathrm{mg} \mathrm{O}_{2} \mathrm{l}^{-1}$, they were abundant (Fig. 7c). On 31 July they were again abundant at the time of the first trawling event during late flood tide when the DO was $\sim 4 \mathrm{mg} \mathrm{O}_{2} \mathrm{l}^{-1}$ (Fig. $7 \mathrm{~d}$ ). The DO decreased with the ebbing tide as the morning progressed, as was the case on 13 July (Fig. 7a). However, by mid-ebb tide on July 31 the DO had not fallen below $3 \mathrm{mg} \mathrm{O}_{2} \mathrm{l}^{-1}$ and weakfish were still abundant at the time of the mid-day trawling event. At high tide on 14 August, $2 \mathrm{~d}$ following a heavy thunderstorm that generated high freshwater inflow amid a period of extremely hot weather, the upper creek was severely hypoxic and fish were absent at the time of the sunrise trawling event (Fig. $7 \mathrm{~g}$ ). This was the only high tide trawling event of the study that yielded no fish. It was 

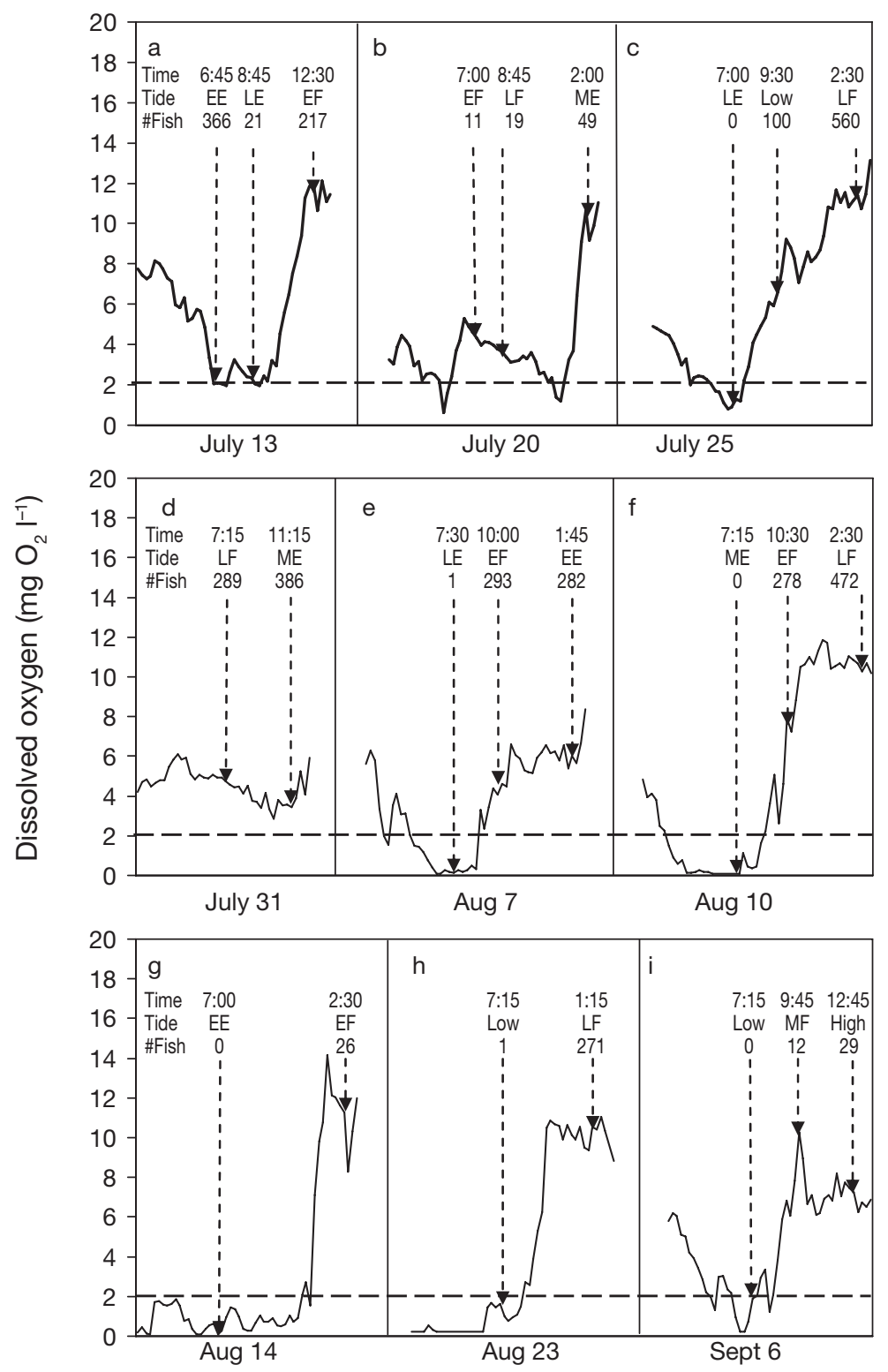

Fig. 7. Juvenile weakfish Cynoscion regalis catches and time series plots of dissolved oxygen concentration at the upper Pepper Creek site on 9 dates (a-i) during the summer of 2001. Each vertical dashed line indicates a trawling event ( 4 trawl tows per event with the exception of July 25 2nd event, which was only 2 tows due to unusually low tide and shallow water). Each time series begins at 02:00 $\mathrm{h}$ and ends within $1 \mathrm{~h}$ after the last trawling event of the sampling day. Tidal stage is denoted as early (E), middle (M), or late (L) and tidal phase as ebb (E), flood (F), low, or high

also the only high tide trawling event when the DO was $<2 \mathrm{mg} \mathrm{O}_{2} \mathrm{l}^{-1}$. The weather effect on DO was so severe on this date that the bottom DO did not rebound to $2 \mathrm{mg} \mathrm{O}_{2} \mathrm{l}^{-1}$ until the flood tide began around noon, at which time a small number of fish moved back into the upper creek area (Fig. 7g).

Having established that when DO was $<2 \mathrm{mg} \mathrm{O}_{2} \mathrm{l}^{-1}$ juvenile weakfish left the upper creek, the next step was to try and determine where they went. Therefore, on 4 dates (25 July, and 7, 10, and 14 August), when fish were absent at the upper creek site at sunrise under severely hypoxic conditions, the middle site was sampled immediately thereafter. On the first 3 of these dates the bottom DO at the middle site was at least $2.5 \mathrm{mg} \mathrm{O}_{2} \mathrm{l}^{-1}$ and weakfish were relatively abundant (Fig. 8a to c). Also, in the hours leading up to each of these 3 trawling events the DO was $>2 \mathrm{mg} \mathrm{O}_{2}$ $\mathrm{I}^{-1}$, with the exception of a few minutes on 25 July. On the fourth date, 14 August, bottom DO at the middle site was slightly $<2 \mathrm{mg} \mathrm{O}_{2} \mathrm{l}^{-1}$ at the time of trawling, and, although fish were not absent, abundance was substantially lower (Fig. 8d) than on the preceding 3 dates. Moreover, on 14 August, intermittent drops in DO below $1 \mathrm{mg} \mathrm{O} \mathrm{O}_{2} \mathrm{l}^{-1}$ had occurred in the hours prior to trawling (Fig. 8d). These 4 sampling events illustrate that weakfish were farther down the creek where adequate DO levels (i.e. $>2 \mathrm{mg} \mathrm{O}_{2} \mathrm{l}^{-1}$ ) existed and confirm avoidance of $\mathrm{DO}<2 \mathrm{mg} \mathrm{O}_{2} \mathrm{l}^{-1}$. It is further suggested that fish move up the creek with the flood tide after DO increases, based on a comparison of the early-morning versus mid-day catches at the middle site on 25 July and 7 and 10 August. The total number of fish caught at the middle site in the morning on these 3 dates $(170,39$, 47) was consistently larger than at midday $(121,3,14)$.

There is also evidence that the hot weather and high freshwater inflow associated with the 14 August sampling date extended the bottom-water, severehypoxia condition over the entire length of the creek, causing most weakfish to leave Pepper Creek entirely. On 14 August the number of fish that returned to the upper creek around midday was very low (Fig. 7 g), in comparison to those returning on 7 and 10 August (Fig. 7e,f). Emigration from the creek is further suggested by the fact that no weakfish (or any other fishes) were caught at the lower site in the mid-day sampling on 14 August. It is also clear that low abundance of weakfish on 14 August was not due to seasonal migration because they returned to the upper creek in high abundance by the next sampling date, 23 August (Fig. 7h). 


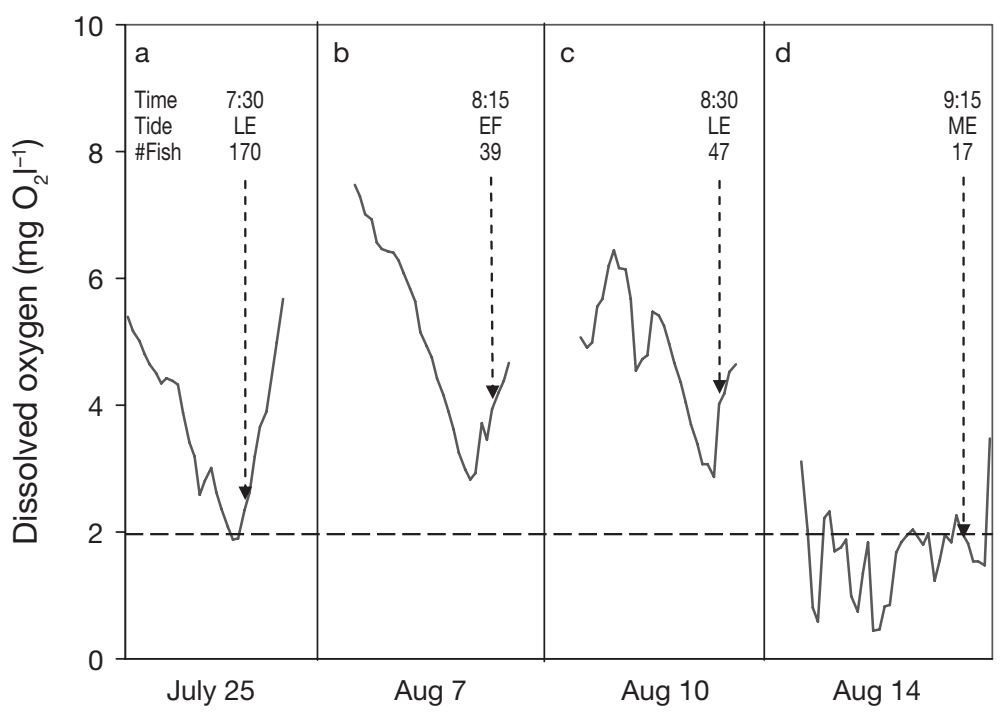

Fig. 8. Juvenile weakfish Cynoscion regalis catches (no. in four $100 \mathrm{~m}$ trawl tows) and time series plots of dissolved oxygen concentration at the middle Pepper Creek site on 4 dates (a-d) during the summer of 2001. Each time series begins at 02:00 $\mathrm{h}$. Tidal stage is denoted as early $(\mathrm{E})$, middle $(\mathrm{M})$, or late

(L) and tidal phase as ebb (E) or flood (F)

On 6 September another sharp decline in weakfish abundance occurred at the upper and middle sites (Figs. 6 \& 7i), similar to that observed on 14 August. However, it is more likely that this reduced abundance was influenced by seasonal migration from the system. This conclusion is based on the fact that the decline in abundance continued through the last sampling event on 20 September (when only 2 weakfish were caught in total at all 3 sites).

\section{DISCUSSION}

Little attention has been given to short-term movements of fishes in response to rapidly changing DO conditions that occur in small tributary habitats (Szedlmayer \& Able 1993). Such habitats, of which Pepper Creek is representative, can develop severe dielcycling hypoxia during summer (Tyler 2004) when juvenile estuary-dependent fishes are abundant (Weinstein 1979, Hoss \& Thayer 1993, Kirby-Smith et al. 2003).

No information has been reported regarding DOrelated effects upon weakfish Cynoscion regalis, other than that by Mercer (1989), who stated that concentrations between 1 and $2.3 \mathrm{mg} \mathrm{O} \mathrm{O}^{-1}$ blocked juvenile movement up the Delaware River, USA. In the current study, juvenile weakfish were present in Pepper Creek at varying levels of abundance when DO was $>2 \mathrm{mg} \mathrm{O}_{2}$ $\mathrm{l}^{-1}$ and were very scarce or absent when DO was lower. In the laboratory, juvenile weakfish avoided 1 but not $2 \mathrm{mg} \mathrm{O}_{2} \mathrm{l}^{-1}$ (Tyler 2004). These findings are consistent with the general statement by Mercer (1989), and indicate that the avoidance threshold for juvenile weakfish is similar to that exhibited by other juvenile sciaenids including spot and croaker Micropogonias undulatus, and other juvenile estuary-dependent fishes in estuaries along the Atlantic Coast of the USA (Pihl et al. 1991, Eby \& Crowder 2002, Bell \& Eggleston 2005).

During the mid-summer 2001 period of peak abundance, juvenile weakfish were most abundant in the upper part of Pepper Creek where DO conditions dictated that they avoid at least 1 severe hypoxia event (persisting for minutes to hours) per day. Sampling results strongly indicated that movements to and away from the upper site were DO related. Juvenile weakfish occupied the upper creek during all tidal stages and across the full range of temperature and salinity conditions when DO was $\geq 2 \mathrm{mg} \mathrm{O}_{2} \mathrm{l}^{-1}$, and were absent or scarce when and wherever hypoxia was severe.

The suggested preference of juvenile weakfish for the upper creek agrees with numerous sources that have reported high abundance of many juvenile estuary-dependent fishes in lower salinity areas of estuaries relative to higher salinity areas (Gunter 1957, Massman 1971, Miller et al. 1985, Paterson \& Whitfield 2000), some of which develop low DO (Meng et al. 2002, Kirby-Smith et al. 2003). Collectively, these reports suggest that moderate eutrophication may be beneficial, or at least not detrimental, to fish production, even though DO cycling to extremely low levels can cause fish to temporarily leave some areas. More research is required to definitively establish the underlying basis and cause(s) of this often observed phenomenon, the benefit of this behavior to fish production, and the extent to which fish production may be impacted by frequent movement away from areas that intermittently develop severe hypoxia.

In small habitats such as Pepper Creek, DO dynamics occur on small temporal and spatial (vertical and horizontal) scales. Considering the rapid reappearance of juvenile weakfish in the upper creek following an increase in DO to moderately hypoxic or normoxic levels on several sampling dates, it is evident that they do not move far. Based on the established premise discussed thus far that the DO-related avoidance response in fishes occurs at around $2 \mathrm{mg} \mathrm{O}_{2} \mathrm{l}^{-1}$ (Garlo et al. 1979, Pihl et al. 1991, Lenihan et al. 2001, Eby \& Crowder 2002, Bell \& Eggleston 2005) then, in the present study, the area of Pepper Creek, which fish would be expected to routinely vacate, should have been limited to approximately the upper 1 to $1.5 \mathrm{~km}$. 
It also appears that they routinely moved down the creek with the ebbing tide to stay in DO levels of at least $2 \mathrm{mg} \mathrm{O}_{2} \mathrm{l}^{-1}$. For example, on the first occasion that we observed hypoxia-induced avoidance of the upper creek (13 July), abundance declined sharply when the vertical DO profile showed a drop to $2.0 \mathrm{mg}$ $\mathrm{O}_{2} \mathrm{l}^{-1}$ (Fig. 4a, Panel 2). It is notable that the channel bottom (where vertical profiles were conducted) was $\sim 0.45$ to $0.6 \mathrm{~m}$ deeper than the channel flank on which the sonde was positioned, and that $96 \%$ of the 366 weakfish taken in the sunrise trawling event had been in this relatively deep water. At the time the weakfish declined in abundance, the bottom DO measured by the sonde on the slightly shallower channel flank was higher $\left(2.3 \mathrm{mg} \mathrm{O}_{2} \mathrm{l}^{-1}\right)$. It follows that, had the fish simply moved vertically in the water column (DO in the channel was $2.8 \mathrm{mg} \mathrm{O}_{2} \mathrm{l}^{-1}$ at a depth of $0.9 \mathrm{~m}$ above the bottom) (Fig. $4 \mathrm{a}$, Panel 2) or laterally into the shallows shoreward of the sonde where it is likely that DO was $>2.0 \mathrm{mg} \mathrm{O}_{2} \mathrm{l}^{-1}$ ), more would have been caught during the second trawling event. It is also very unlikely that juvenile weakfish moved further up Pepper Creek, against the tide, and into lower DO conditions. Lower DO levels upstream of the upper site are strongly suggested by the continued decrease in bottom and near-bottom DO throughout the remainder of the ebb tide (Fig. 4a, Panel 3) and the clear overall trend of decrease in DO with distance up the tributary along the entire length of Pepper Creek throughout the season (Fig. 3). The absence of weakfish in these trawl samples during severe hypoxia, even though the mouth of the trawl extended well above the bottom, and often to the surface in the shallower areas, strongly suggests movement out of the area altogether and in the downstream direction. It would be difficult to ascertain the relative importance of the tide, or an increasing gradient of DO, as directional cues because fish movement away from the upper site almost always coincided with ebb tide and DO was almost always higher with distance downstream.

Movement of juvenile weakfish closer to shore into water too shallow $(<0.5 \mathrm{~m})$ to trawl in during either normoxia or severe hypoxia conditions is also not supported by observations during the present study, directed sampling efforts, or previous studies. For example, at sunrise on 7 August, when the near-sunrise profile for the upper creek showed severe hypoxia (i.e. $<1 \mathrm{mg} \mathrm{O}_{2} \mathrm{l}^{-1}$ ) throughout the water column, blue crabs were observed at the shoreline in very shallow water $(<15 \mathrm{~cm})$, but no fish were seen. The moribund state of the crabs, the lack of fish activity, and similar appearance of the water (turbid with deep mahogany hue indicative of high phytoplankton density) along the shoreline strongly suggested DO conditions similar to the severe hypoxia in the middle of the creek, $\sim 50 \mathrm{~m}$ away. Furthermore, seining along the shoreline of upper Pepper Creek during mid-afternoon on 18 July yielded $<10$ juvenile weakfish, whereas 10 s to 100 s of individuals of other species including silversides Menidia sp., mummichog Fundulus heteroclitus, and spot were collected. A similar scarcity of juvenile weakfish in very shallow nearshore waters was reported by Derickson \& Price (1973), who found that weakfish accounted for only 39 of 41286 fish collected in an extensive shore zone seining survey of 18 sites in Indian River Bay and Rehoboth Bay during the summers of 1968 to 1969. Moreover, recent results from a large-scale trawling/seining survey of the Maryland Coastal Bays showed that all but 4 of 2464 juvenile weakfish were collected by trawl in waters $\geq 1 \mathrm{~m}$ deep (Casey \& Doctor 2003).

Most fish did not appear to move as far down the creek as the middle site to avoid the extreme DO conditions in the upper creek. On the $3 \mathrm{~d}$ that juvenile weakfish were caught during early morning at the moderately hypoxic middle creek site (when absent from the severely hypoxic upper creek), abundance was much less than observed in the upper creek later in the day after DO had increased. To examine this possibility, exploratory DO measurements and trawling (three $100 \mathrm{~m}$ tows) were conducted on 10 August at 09:45 h (immediately after sampling the middle site) about halfway between the upper and middle sites. The bottom DO was $2.4 \mathrm{mg} \mathrm{O}_{2} \mathrm{l}^{-1}$, and the number of weakfish caught $\left(57\right.$ tow $\left.^{-1}\right)$ was higher than at the middle site $\left(12\right.$ tow $\left.^{-1}\right)$. This catch from between the upper and middle sites was similar to the number of weakfish caught immediately thereafter at the upper site (70 tow ${ }^{-1}$ at 10:30 h), but did not account for the much higher abundance caught later in the afternoon at the upper site (118 tow ${ }^{-1}$ at $14: 30 \mathrm{~h}$ ). It is possible that the fish moving up the creek during the period between the second and third trawling events were steadily concentrating at the upper site. Unfortunately, bottom debris prevented exploratory trawling in an area several hundred meters farther down the creek in the direction of the middle site, thus the morning sampling of the area between the upper and middle sites was limited. Nonetheless, these data show that when the down-creek extent of severe hypoxia was within the area between the upper and middle sites, then fish occurred where the DO was at least $2 \mathrm{mg} \mathrm{O} \mathrm{O}^{-1}$. This indicated that unless severe hypoxia extended down to the middle site or beyond due to weather conditions, weakfish at the upper site only needed to move $\sim 1.0$ to $1.5 \mathrm{~km}$ down Pepper Creek to remain within water with a DO of about $2 \mathrm{mg} \mathrm{O}_{2} \mathrm{l}^{-1}$.

The swimming capabilities of juvenile weakfish of the size present in Pepper Creek during summer (50 to 
$150 \mathrm{~mm} \mathrm{TL}$; see Tyler 2004) would appear sufficient to allow fish to move from the upper site down as far as the middle site. Breitburg (1992) noted that sustained swimming speed in fishes generally averages $\sim 3$ to 5 body lengths (BL) $\mathrm{s}^{-1}$. In the laboratory, juvenile weakfish exhibited a voluntary swimming speed of 1.5 to $1.8 \mathrm{BL} \mathrm{s}^{-1}$ under normoxic conditions, increasing to $2 \mathrm{BL} \mathrm{s}^{-1}$ and sometimes $>3 \mathrm{BL} \mathrm{s}^{-1}$ when exposed to hypoxic conditions (Damian Brady pers. comm.). In the field, juvenile spot fitted with transmitters exhibited a wide range of swimming speeds when avoiding low oxygen (0.5 to $3.5 \mathrm{BL} \mathrm{s}^{-1}$ ) (Kevin Craig pers. comm.). Thus, a weakfish of $100 \mathrm{~mm}$ TL swimming continuously (in a straight line) and at an average speed of $2 \mathrm{BL} \mathrm{s}^{-1}$ would take about $1.5 \mathrm{~h}( \pm$ depending on current direction) to swim $1 \mathrm{~km}$ and conceivably reach an area with a DO level $>2 \mathrm{mg} \mathrm{O}_{2} \mathrm{l}^{-1}$. Furthermore, fish movement from the upper site was almost always observed to coincide with ebb tidal flow, which would make movement to higher oxygenated water down the creek easier.

The impact on juvenile weakfish of short-term (dielcycling) hypoxia dynamics and frequent abandonment of seemingly preferred habitat in Pepper Creek (e.g. density-dependent processes etc.) is unclear. Lack of access to the upper creek during severe hypoxia events would seem to concentrate juvenile fishes outside of the temporarily uninhabitable area and potentially place them into closer proximity with predators such as larger fishes and blue crabs. However, the areas of Pepper Creek in which juvenile fishes were found during times of severe hypoxia in the upper creek were not much above $2 \mathrm{mg} \mathrm{O} \mathrm{O}^{-1}$, and would also likely be very stressful to older predatory fish. Predatory fishes that utilize the Delaware coastal bays in significant numbers include adult weakfish, summer flounder, bluefish Pomatomus saltatrix, and striped bass Morone saxatilis. All these species are popular gamefish, and there was no evidence of fishing effort that would suggest they are present in significant numbers during summer in the tributaries (Robin Tyler pers. obs.). Adult and late-stage juvenile blue crabs are abundant during summer in Pepper Creek; however, Bell et al. (2003) reported that their feeding rates were somewhat suppressed when exposed to DO levels between 2 and $4 \mathrm{mg} \mathrm{O}_{2} \mathrm{l}^{-1}$. Eby \& Crowder (2002) reported that blue crabs infrequently capture live fish, but did point out that habitat compression would increase blue crab-fish encounters.

The main factor motivating juvenile weakfish to concentrate in the upper part of Pepper Creek may be food availability. Juvenile anchovies Anchoa sp. and mysid shrimp Neomysis americana are 2 of the most important food sources of juvenile weakfish (Merriner 1975, Mercer 1989, Grecay \& Targett 1996), and both were collected as bycatch in this study. Although mysids decreased in abundance after the water temperature exceeded $25^{\circ} \mathrm{C}$ (before juvenile weakfish appeared), the period during which juvenile anchovies were abundant overlapped with that of juvenile weakfish. Early-juvenile anchovies $(\sim 20 \mathrm{~mm}$ standard length) first appeared in abundance on 5 July and, thereafter, through August; $76 \%$ of the total anchovy catch occurred at the upper creek site (Tyler 2004).

It would be helpful to understand whether juvenile weakfish and other juvenile fishes that utilize the upper segments of estuarine tributaries, where DO dynamics are dominated by diel-cyclic fluctuation and severe hypoxia frequently develops (Tyler 2004), use these areas in spite of, or because of, the temporarily stressful/potentially lethal DO conditions. It is quite clear that human-related acceleration in the rate of eutrophication has caused a worldwide increase in coastal area affected by severe hypoxia, and an intensification of hypoxia in areas naturally affected (Diaz et al. 2004).

Weakfish in Pepper Creek only moved $\sim 1 \mathrm{~km}$ to avoid water that had lethally low DO. A possible consequence of extending the severe hypoxia zone farther down the tributary could be avoidance of larger segments of habitat, or even complete abandonment of the upper creek due to the increased distance fish would have to swim on a tidal cycle to reach it. A further consequence of this would be a decrease in usable habitat, with potential ramifications regarding density-dependent feeding, growth, and predation.

This research demonstrates that juvenile weakfish are able to consistently avoid potentially lethal DO conditions, which occur on a diel cycle and a spatial scale small enough to swim away from. Their rapid movements back into these areas as DO conditions improve and their relatively high density in tidal tributary headwaters further suggests that these relatively small areas provide important habitat for fishes.

Acknowledgements. Funding was provided by the Center for the Inland Bays under United States Environmental Protection Agency Grant No. CE-99399002 to R.M.T. In-kind services were provided by the Delaware Department of Natural Resources and Environmental Control and the National Sea Grant Office, NOAA, U.S. Department of Commerce, under Grant Numbers NA96RG0029 (Project R/F-17) and NA16RG0162-03 (Project R/F-21) to T.E.T. We thank all who participated in the field sampling including B. Barber, D. Brady, S. Brown, M. Crane, E. Dickey, S. Huerta, G. Mitchell, J. Nye, J. Rager, K. Ranck, S. Schmidt, and K. Stierhoff. Special thanks are extended to K. Stierhoff for editing the manuscript, and to P. Gaffney for assistance with statistical analysis. Helpful comments on earlier drafts of the manuscript were provided by R. Diaz, C. Epifanio, and K. S. Price. The research presented in this paper has not been subjected to the USEPA required peer review and policy review and therefore does not necessarily reflect the views of the agency. 


\section{LITERATURE CITED}

Beck NG, Bruland KW (2000) Diel biogeochemical cycling in a hyperventilating shallow estuarine environment. Estuaries 23:177-187

Bejda AJ, Phelan BA, Studholme AL (1992) The effect of dissolved oxygen on the growth of young-of-the-year winter flounder, Pseudopleuronectes americanus. Environ Biol Fish 34:321-327

Bell GW, Eggleston DB (2005) Species-specific avoidance responses by blue crabs and fish to chronic and episodic hypoxia. Mar Biol 146:761-770

Bell GW, Eggleston DB, Wolcott TG (2003) Behavioral responses of free-ranging blue crabs to episodic hypoxia. II. Feeding. Mar Ecol Prog Ser 259:227-235

Breitburg DL (1992) Episodic hypoxia in Chesapeake Bay: interacting effects of recruitment, behavior, and physical disturbance. Ecol Monogr 62:525-546

Burton DT, Richardson LB, Moore CJ (1980) Effect of oxygen reduction rate and constant low dissolved oxygen concentrations on two estuarine fish. Trans Am Fish Soc 109: $552-557$

Casey JF, Doctor SB (2003) Investigation of Maryland's Atlantic Ocean and coastal bay finfish stocks. Federal Aid Project No. F-50-R-13, Maryland Department of Natural Resources Fisheries Service, Annapolis, MD

D'Avanzo C, Kremer JN (1994) Diel oxygen dynamics and anoxic events in an eutrophic estuary of Waquoit Bay, Massachusetts. Estuaries 17(1B):131-139

Derickson WK, Price KS Jr (1973) The fishes of the shore zone of Rehoboth and Indian River Bays, Delaware. Trans Am Fish Soc 3:552-561

Diaz RJ, Rosenberg R (1995) Marine benthic hypoxia: a review of its ecological effects and the behavioral responses of benthic macrofauna. Oceanogr Mar Biol Annu Rev 33:245-303

Diaz RJ, Nestlerode J, Diaz ML (2004) A global perspective on the effects of eutrophication and hypoxia on aquatic biota. In: Rupp GL, White MD (eds) Proceedings of the 7th international symposium on fish physiology, toxicology, and water quality. EPA 600/R-04/049, U.S. Environmental Protection Agency, Ecosystems Research Division, Athens, GA, p 1-33

Eby LA, Crowder LB (2002) Hypoxia-based habitat compression in the Neuse River Estuary: context-dependent shifts in behavioral avoidance thresholds. Can J Fish Aquat Sci 59:6 952-965

Eby LA, Crowder LB, McClellan CM, Peterson CH, Powers MJ (2005) Habitat degradation from intermittent hypoxia: impacts on demersal fishes. Mar Ecol Prog Ser 291: 249-261

Garlo EV, Milstein CB, Jahn AE (1979) Impact of hypoxic conditions in the vicinity of Little Egg Inlet, New Jersey in summer 1976. Estuar Coast Mar Sci 8:421-432

Grecay PA, Targett TE (1996) Spatial patterns in condition and feeding of juvenile weakfish in Delaware Bay. Trans Am Fish Soc 125:803-808

Gunter G (1957) Predominance of the young among marine fishes found in freshwater. Copeia 1:13-16

Hoss DE, Thayer GW (1993) The importance of habitat to the early life history of estuarine dependent fishes. Am Fish Soc Symp 14:147-158

Howell P, Simpson D (1994) Abundance of marine resources in relation to dissolved oxygen in Long Island Sound. Estuaries 17:394-402

Kemp WM, Boynton WR (1980) Influence of biological and physical processes in dissolved oxygen dynamics in an estuarine system: implications for measurement of community metabolism. Estuar Coast Mar Sci 11:407-431

Kirby-Smith WW, Lebo ME, Herrman RB (2003) Importance of water quality to nekton habitat use in a North Carolina branch estuary. Estuaries 26:1480-1485

Lenihan HS, Peterson $\mathrm{CH}$, Byers JE, Grabowski JH, Thayer GW, Colby DR (2001) Cascading of habitat degradation: oyster reefs invaded by refugee fishes escaping stress. Ecol Appl 11:764-782

Maes J, Van Damme PA, Taillieu A, Ollevier F (1998) Fish communities along an oxygen-poor salinity gradient (Zeeschelde Estuary, Belgium). J Fish Biol 52:534-546

Massman WH (1971) The significance of an estuary on the biology of aquatic organisms of the Middle Atlantic Region. In: Douglas PA, Straud RH (eds) Proceedings of a symposium on the biological significance of estuaries. Sport Fishing Inst., Washington, DC, p 96-109

Meng L, Orphanides CD, Powell JC (2002) Use of a fish index to assess habitat quality in Narragansett Bay, Rhode Island. Trans Am Fish Soc 131:731-742

Mercer LP (1989) Species profiles: life histories and environmental requirements of coastal fishes and invertebrates (mid-Atlantic) weakfish. Biol Rep US Fish Wildl Serv 82(11.109)

Merriner JV (1975) Food habits of the weakfish, Cynoscion regalis, in North Carolina. Chesapeake Sci 16:74-76

Michels SF (1986-2005) Annual coastal finfish assessment survey reports. Fisheries Program, State of Delaware, DNREC, Division of Fish and Wildlife, Dover, DE

Miller DC, Poucher SL, Coiro L (2002) Determination of lethal dissolved oxygen levels for selected marine and estuarine fishes, crustaceans, and a bivalve. Mar Biol 140:287-296

Miller JM, Crowder LB, Moser ML (1985) Migration and utilization of estuarine nurseries by juvenile fishes: an evolutionary perspective. In: Migration: mechanisms and adaptive significance. Contrib Mar Sci 68:338-352

Nestlerode JA, Diaz RJ (1998) Effects of periodic environmental hypoxia on predation of a tethered polychaete, Glycera americana: implications for trophic dynamics. Mar Ecol Prog Ser 172:185-195

Officer CB, Biggs RB, Taft JL, Cronin LE, Tyler MA, Boynton WR (1984) Chesapeake Bay anoxia: origin, development, and significance. Science 223:22-27

Paterson AW, Whitfield AK (2000) Do shallow-water habitats function as refugia for juvenile fishes? Estuar Coast Shelf Sci 51:359-364

Pihl L, Baden SP, Diaz RJ (1991) Effects of periodic hypoxia on distribution of demersal fish and crustaceans. Mar Biol 108:349-360

Pihl L, Baden SP, Diaz RJ, Schaffner LC (1992) Hypoxiainduced structural changes in the diet of bottom-feeding fish and Crustacea. Mar Biol 12:349-361

Price KS, Flemer DA, Taft JL, Mackiernan GB, Nehlsen W, Biggs RB, Burger NH, Blaylock DA (1985) Nutrient enrichment of Chesapeake Bay and its impact on the habitat of striped bass: a speculative hypothesis. Trans Am Fish Soc 114:97-106

Shimps EL, Rice JA, Osborne JA (2005) Hypoxia tolerance in two juvenile estuary-dependent fishes. J Exp Mar Biol Ecol 325:146-162

Sokol RR, Rohlf FJ (2001) Biometry-The principles and practice of statistics in biological research. WH Freeman and Company, New York

Stanley DW, Nixon SW (1992) Stratification and bottom-water hypoxia in the Pamlico River estuary. Estuaries 3:270-281

Stierhoff KL, Targett TE, Miller KL (2006) Ecophysiological responses of juvenile summer flounder and winter floun- 
der to hypoxia: experimental and modeling analyses of effects on estuarine nursery quality. Mar Ecol Prog Ser 325:255-266

Szedlmayer ST, Able KW (1993) Ultrasonic telemetry of age-0 summer flounder (Paralichthys dentatus) movements in a southern New Jersey estuary. Copeia 1993(3):728-736

Tyler RM (2004) Distribution and avoidance patterns of juvenile summer flounder (Paralichthys dentatus) and weakfish (Cynoscion regalis) in relation to hypoxia: field studies in a temperate coastal lagoon tributary and laboratory

Editorial responsibility: Robert Feller (Contributing Editor), Columbia, South Carolina, USA choice experiments. PhD dissertation, Graduate College of Marine Studies, University of Delaware, Lewes, DE

USEPA (United States Environmental Protection Agency) (2000) Ambient water quality criteria for dissolved oxygen (saltwater): Cape Cod to Cape Hatteras. EPA 822-D99-002, USEPA, Office of Water 4304, November 1999. Available at: www.epa.gov/ost/standards/dissolved

Weinstein MP (1979) Shallow marsh habitats as primary nurseries for fishes and shellfish, Cape Fear River, North Carolina. Fish Bull 77:339-357

Submitted: February 27, 2006; Accepted: August 7, 2006 Proofs received from author(s): February 28, 2007 